\title{
The relative weight of subject knowledge and type of university attended: a comparison of Law higher education in England and Germany
}

\author{
Anna Mountford-Zimdars, King's College London, UK and John Flood, Griffith University, \\ Brisbane, Australia
}

This paper explores the relationship between legal practice and type of university attended and degree course studied for English and German lawyers. For England, some of the analysis is only based on data for barristers. We find that university attended matters a great deal for English barristers if they tend to have graduated from elite universities within the stratified British higher education system. In contrast, the flat German higher education system is also mirrored in the profile of lawyers were graduates in the top jobs come from a wide range of institutions. For Germany, attainment at university and graduating in law are keys to unlocking elite positions whereas the status of university seems second to none in the British system, trumping having studied law as a first degree. The paper thus empirically confirms anecdotal insights that knowledge and skills directly related to law matters more for early career entry in Germany and generic skills and socialization at elite universities matters more for transitioning into elite legal employment in England. It is unclear from the available data whether the different structures mean that the social make-up of the legal professions differs, but it is clear that different ways of accessing this key profession operate in the two contexts.

\section{Introduction}

Law is one of the longest-standing professions in the world and lays a strong claim to being the oldest profession associated with university education. The longest continuously operating European university, Bologna, was set up in 1088 specifically with the aim of studying a key document from $6^{\text {th }}$ century Roman Law (Mommsen et al., 1985). The oldest English speaking university, Oxford, first taught in the three key areas - theology, medicine, and law - although at the time, theology or divinity arguably held a higher status than either law or medicine.

Lawyers are also some of the most powerful professionals groups. The social and educational background of lawyers, their values and how representative they are of society matters for access to justice (e.g. Hunter, 2015; Schultz and Shaw, 2013). Who the lawyers are also shapes the content of law and judgments as law evolves to mirror changing social norms, let it be in relation to the role of women, sexual norms or types and length of penalties. Some have argued that who lawyers are shapes law even more in Common Law jurisdictions based 
on case-law like England compared with the impact individuals have in codified Roman Law jurisdictions like Germany.

Lawyers also have an impact on other areas of public life and beyond as many law graduates draw on their legal background for their positions in other occupations. For example, 14 per cent of German MPs and 13 per cent of MPs in the Westminster Parliament are lawyers (Gradl 2013; McGuinness, 2010, p. 5). Finally, lawyers capture the public imagination through popular television and reality programmes across countries and they have recently replaced aristocrats and doctors as the most eligible profession in romantic fiction (e.g. Fielding 1996).

While often associated with positions of power and privilege, the legal professions in Germany and England are also some of the most internally diverse and stratified professions. Some formally trained in law do not practice law at all due to a lack of access into the profession, a change in their professional trajectory or because they join the academic legal profession. At the same time, a significant proportion of lawyers in England did not study law as their first degree. Earnings among practising lawyers range widely, from very low incomes - often associated with practising in family, public, and criminal law - to the guaranteed 'licence to print money' in the often splendid offices of, for example, German and other continental notaries, to well remunerated judges and the commercial lawyers with stratospheric earnings. Therefore, knowing that someone is a 'lawyer' thus does not necessarily reveal anything about their individual social position, power, prestige, or income.

Against the context of this diverse, yet ancient profession, the present paper explores the relationship between the higher education institution attended, subject studied and practice in the legal profession in two European countries, England and Germany. The empirical analysis first describes the highest echelons of the judiciary in England and Germany. It then draws on original, multivariate empirical research regarding the internal stratification of the English legal Bar. In the absence of individual-level information for Germany, the case of access to the German legal profession is mainly considered in the literature review based on pre-existing research. The paper also draws on one expert interview with an organization representing graduate recruiters.

The paper concludes that both the English and the German legal profession are internally stratified. However, while the prestige of the university attended is key for understanding the stratification of the English Bar, the German legal profession is stratified primarily by grades attained regardless of university attendance. However, the German system also retains a direct inheritance of positions in law through e.g. through inheriting existing legal practices. In terms of social mobility, both legal professions offer some opportunities for upward mobility. In the German system, succeeding in examinations alone can be the ticket to the position that are open in the contest mobility system, although some sections of the legal market are systemically closed to outsiders regardless of educational attainment. It is also possible, particularly for those less affluent (but also in some cases for those wealthy but eligible for merit scholarships) to by-pass the state university system through enrolling at a private law university with more advantageous labour market prospects. However, the standardized state examinations in law means that all law students have to pass the same examination regardless of university attended. In the English system, stellar academic performance should ideally be coupled with graduating from a prestigious university to allow individuals to reap the rewards of their education, thus indicating continuations of elements of sponsorship mobility in the legal profession. 
England and Germany have very different higher education systems. England has a highly stratified system with a tier of elite universities, the 'Russell Group'. These 24 universities command a high percentage of the national research income, they graduate a disproportionate number of doctorates, and admission to one of these universities requires excellent grades in the national school leaving examinations. Within the Russell Group, the universities of Oxford and Cambridge, collectively known as Oxbridge, are outliers in terms of endowment, age, prestige, and the fierce competition for places. For international readers, the status of the Russell Group is perhaps comparable to the Ivy Leagues in the United States or the Grandes Ecoles in France. At the other end of the spectrum, England has numerous universities that used to be polytechnic colleges, these gained university status in 1992 and are often referred to as 'new' or 'post-1992' universities. The differential status of universities maps onto social background with wealthier, whiter, higher attaining students and those educated in private schools disproportionately enrolling at Russell Group institutions and those from nontraditional backgrounds over-represented among students in the post-1992 institutions (Jerrim, 2014; Croxford \& Raffe, 2014). The UK has also recently experienced the arrival of private universities into the higher education market with private providers for especially law conversion courses (explained below) having existed for some time.

Germany has historically had a dual higher education system with universities and 'Fachhochschulen' (universities of applied sciences) built around a parity of esteem among institutions in each group. There has been a recent founding wave of private universities including the Bucerius law school in Hamburg founded in 2000. Moreover, the German government is actively attempting to create recognizable elite universities through the Excellenzinitiative which has seen additional funding for selected universities since its inception in 2005. However, recognition of excellence is based on research rather than teaching meaning that law graduates, regardless of university attended, have to succeed in the state examinations.

When the judges who are analysed in this paper participated in secondary education, many would have participated in a tripartite system of education in both countries with early selection into grammar schools or Gymnasium and secondary moderns (England) or Realschule und Hauptschule in Germany with England also continuing to have a thriving elite private schooling sector along the state sector. In both countries, early streaming is associated with socio-economic status. Some of the younger justices and certainly the younger barristers in England would have grown up in a secondary school system that had been largely comprehensivised meaning that most local education authorities abolished early selection at the age of 11 in the 1970s, thus potentially creating greater upward social mobility opportunities. These different funnels of earlier education opportunity must be born in mind when judging levels of stratification in higher education.

Not only are the university macro-structures different in Germany and England, the way law is studied is also different. Law is a graduate degree course in Germany, meaning students have to pass through an undergraduate degree and then additional training to qualify as lawyers. The standard time to the first state examination is 4.5 years ( 9 semesters $)$ although 
most students take between 10.5-11 semesters (5-6 years). Passing this examination alone does not entitle students to practise law. Instead, a further two years of practical training are required cumulating in the second state examination. Passing this examination allows students to be 'Volljuristen' meaning that they can now access the full range of branches of the legal profession (state prosecutor, lawyer, judge, notary). Higher education is generally free with nominal charges, although most law graduates also participate in paid-for revision classes with a 'Repetitor'. Means tested support for low-income students is available for university study.

Aspiring lawyers in England can study law as a first degree at university. However, surprisingly to observers from other European countries, it is also possible for students with undergraduate degrees in other disciplines to undertake a one-year (full-time) conversion course, the Graduate Diploma in Law. This conversion course is offered by universities as well as private providers. Regardless of whether students have a three-year law degree or hold a one-year conversion course completion, they can then access the same two options for further training. The most common option is another one-year academic course, the legal practice course to become a solicitor and a subsequent two year training contract with a law firm. The second option is taking the Bar Professional Training Course and subsequently undertaking a one year training period in a barrister's chambers with a view to joining those chambers and becoming a barrister. Law degrees in England are charged at the same rate as other degrees with the standard rate at a Russell Group university being $£ 9,000$ per annum, although these fees are only paid once students graduate and earn above a certain earning threshold. The further training for the Bar or to become a solicitor usually costs more. Means-tested bursaries are available for undergraduate degrees and there are some limited scholarship opportunities for those attending the training to become a barrister or solicitor.

Review: The stratification of legal professions in Germany and England

England

Law is considered a key social mobility profession. Who senior lawyers are, their social and educational background is considered an indicator of the openness of society. A report by the charity the Sutton Trust shows that despite fewer than 7 per cent of English children participating in private schooling, 71 per cent of the most senior barristers (Queen's Counsel) were privately educated. Oxbridge graduation is prevalent with 74 per cent of senior judges, 78 per cent of top QCs and 55 per cent of solicitor partners in magic circle firms having graduated from Oxbridge (Sutton Trust 2005).

Two previously published articles (anonymized for peer review) investigated the predictors for gaining access to the last stage of training for becoming a barrister in England and Wales. This stage in training is called pupillage and the data set used for the previous analysis is also the basis of the present article (with further details provided below in the methods section).

The previous work found firstly that there is a strong association between type of university attended, attainment, gender, age, ethnicity, and gaining a pupillage. Graduates from Oxford and Cambridge are over-represented among those gaining a pupillage, but these Oxbridge graduates are also more likely to be male, white, and middle class but also higher attaining at university and in their Bar course than other students (Zimdars 2011). In turn, especially 
Bangladeshi and Pakistani (and working class students where this information is available) are over-represented among graduates from non-Russell Group universities and underrepresented among high achievers and those gaining a pupillage. A logistic regression analysis then demonstrated that it is attainment and university attendance that drive the differential transition into pupillage for different social groups. In other words, Oxbridge graduates, those with a high grade in their first degree and those with a grade of 'outstanding' in their Bar course are most likely to obtain pupillages. Due to the structure of higher education, these individuals are also more likely to be white and younger (i.e. recent school graduates), and in the particular case of the legal Bar, also more likely to be male.

The work also analysed the status and prestige of entering different branches of the legal profession and found that those entering the employed bar, that is working for the state for example by being a state prosecutor, rather than the higher prestige self-employed bar had lower qualifications, had attended less prestigious universities, were more likely to be female and to have declared a disability (Zimdars 2010). Women already earned less than men at this very early career stage in law. Work on the career transitions of solicitors is also available. This work shows that while women and minorities are well represented among new solicitors, segmentation occurs across gendered, raced and classed lines with e.g. white graduates from higher socio-economic groups over-represented in large City firms and ethnic minority women and those from lower socio-economic groups concentrated in small High Street practices (e.g. Sommerlad et al., 2013).

\section{Germany}

Previous work in Germany has also found that degree grades are central to understanding labour market transitions for law graduates. In contrast to England, employment for lawyers in the state 'employed' sector is highly desirable - state employed lawyers have guaranteed jobs for life with good salaries and there is high social prestige attached to being a stateprosecutor. German judges are also selected based on their grades in their two state examinations, so are recruits to the large law firms. The general cut-off grade here for entry to desirable employments is a grade of 'Vollbefriedigend' (fully satisfactory). In 2010, 30 percent of law graduates achieved this grade or higher in their first state examination (Wissenshaftsrat 2012). When looking at who achieves a grade of 'Gut'(good) or higher in the second state examination, only 15 per cent of graduates fall into this category (Bülow, 2013) and are thus eligible for these top jobs. In addition, private companies also like to see $\mathrm{PhD}$ or LLM degrees and the select few students who graduate with the top grades and those credentials can command six-figure starting salaries (van Lijnden, 2011). It may still be possible to enter these firms without such advanced degrees, but starting salaries would be lower. Private employers also value internships, international experience, and knowledge of English with some also valuing business understanding and work experiences outside universities (Zimmermann 2014). In terms of opportunities to study abroad, only 3-5 per cent of working class students have studied abroad compared with 10-11 per cent of students from families whose parents are higher-level civil servants or self-employed (Bargel, 2007).

With a lower degree grade of 'Ausreichend' (sufficient) or below, in other words, the grade achieved by the vast majority of up to 85 per cent of law students, labour market prospects in an over-saturated market are not promising, as one observer notes: "For a long time, the profession of lawyer was considered a guarantee for professional prestige and a good to excellent income. However, this is not true anymore: Many lawyers can hardly make a living from their craft." (Buchhorn, 2013, author's translation). Another commentator compared 
the job prospects for those who failed to achieve a 'Vollbefriedigend' to the ones of a good cleaner (van Lijnden, 2011).

Even though Germany has, at least until the recent 'Excelenzinitiative', not had a formal system of elite universities, there are notable differences in attainment averages by university. High degree averages are reported at the University of Koeln and the only private law university, the Bucerius Law School Hamburg, while low averages are reported at most other universities at e.g. the Technical University Dresden (Wissenshaftsrat 2012).

Furthermore, possession of PhDs and experiences of living, study and working internationally influence the probability of being hired by a private firm in Germany. Here, it is noteworthy that aspiration for doctorates correlates with social origin. Historically, PhDs were very much an upper class pursuit in Germany, but while this has changed in disciplines like engineering, which have become more open to lower social strata, the reverse trend has occurred in law $\mathrm{PhDs}$ where the relationship between privileged background and $\mathrm{PhDs}$ has strengthened (Harmann 2002 p. 59). Today, twice as many German middle class students aspire to undertake a $\mathrm{PhD}$ compared to working class students and this trend is believed to be particularly pronounced in medicine and law (Bargel and Bargel 2010). A law PhD is considered a good preparation for senior administration - in Hartmann's seminal study of 15 senior political leaders, 11 had law PhDs (Hartmann 2002 p. 97) and the current recruitment wish-list by leading law firms includes a doctorate or LLM for new hires (Zimmermann 2014). A caveat to these findings is that in e.g. Engineering, a PhD might be a requirement for getting certain research and private sector job whereas in law, PhDs might be desirable, give an edge in the competition, increase salaries and potentially status but without being essential for the opportunity to practice.

Moreover, direct social reproduction of children following in their father's footsteps has historically been particularly high for medicine and law in Germany (Dahrendorf 1965). This finding has not changed where recent statistical analyses have shown that half of new law students had a parent who is a lawyer. Only medicine has a higher reproduction rate with 61 per cent of trainee doctors also having a parent who is a doctor (Bargel 2007 $)$.

\section{Analysis}

This paper adds to the existing literature on the legal profession and their education by presenting a three-part new empirical analysis. First, the university background of leading judges in Germany and the UK is established and compared. Second, an empirical analysis of individual-level data of new barristers in England is offered and third, insights from an expert interview are considered. While this methodology is somewhat disjointed, it is trying to get to the key area of interest - lawyers and their educational background - in the absence of directly comparable data or institutions that shape the legal space.

The rationale for establishing the educational background of leading lawyers is that it says something about the profile of the sort of person who has been successful in reaching the highest echelons of the profession in the past. This new analysis focused on the link between family background, university attended and career outcomes for those educated as lawyers

\footnotetext{
${ }^{1}$ The German original is a little unclear whether the reproduction here is directly from father-lawyer to childlawyer or a more general middle-class reproduction pattern.
} 
over 40 years ago. It establishes a 'baseline' through which to consider more recent trajectories and changes to the composition of the legal profession. This element of the research involved looking up the educational biographies of the 12 justices of the UK Supreme Court, the final court of appeal for UK civil cases and criminal law cases from England, Wales and Northern Ireland. For Germany, the biographies of selected judges at the three most prestigious German courts, the Bundesgerichtshof (Federal High Court of Justice) the Bundesverwaltungsgericht, (Federal Administrative Court) and the Bundesverfassungsgericht (Federal Constitutional Court) were analysed with regards to the educational background of senior judges. While the Bundesgerichtshof employs a total of 128 judges, the biographies of only the 17 committee chairs were considered as most comparable to the 12 UK supreme court justices. The Bundesverwaltungsgericht employs 54 judges and their biographies were considered as well as the education of the 16 justices appointed to the Bundesverfassungsgericht. The judges at the last of the three courts are appointed for a term of 12 years by the two chambers of the German parliament and tend to have backgrounds as leading legal academics rather than having entered the judging pathway straight after their Staatsexamen.

Second, this article offers new and extended analysis of a unique individual-level data set focused on the historically more elite tier of the legal profession, the English legal Bar, this data set has been used in two previous articles on the English legal profession (Zimdars 2010, 2011). The data set is limited in that it does not include information on solicitors, who form a larger part of recruitment into the legal profession but does arguably serve the purpose of looking in particular at the link between education and elite status within a very internally diverse profession. The data set consists of three of the four Inns of Courts membership records of all those who matriculated on the Bar Vocational Course (now Bar Professional Training course) between 2000 and 2004. These students were tracked as to whether they secured pupillages, and also whether they subsequently secured permanent positions in barristers' chambers (tenancy).

A total of 4,209 complete individual records of British nationals were obtained from the three participating Inns (overseas nationals were excluded from the analysis as many return overseas to practice in other Commonwealth countries). Of these, 2,717 obtained a pupillage and 1,364 obtained a tenancy after their pupillage. In the individual-level data set used for this study, information is available regarding gender, age, and ethnicity. Two of the three Inns also provided information on attainment in the Bar course. Most students had also provided their Inns with information regarding their undergraduate degree-awarding university and their previous university grades and courses, but this information was not consistently collected or entered. The accuracy of records in relation to pupillage and tenancy was manually checked by the Bar Council. Inns do not keep records regarding the social class origin of their members or the type of secondary school attended (state or private), although some attempt was made to obtain this information through the Universities and Colleges Admissions service, the matching was limited. Taking out the missing data, 955 valid observations remain of those who have successfully transitioned from the Bar Vocational Course into pupillage and subsequently into a tenancy in chambers. This excludes any individuals who may have chosen to join the employed Bar, i.e. the civil service rather than being self-employed barristers pursuing their own practice. The Bar chambers where each individually assigned an area of law that is their key area of practice as well as the key client base they serve. 
While, of course, it would have been desirable to undertake a comparative analysis with individual-level data for German lawyers, such detailed analysis is not possible. The main reason for the absence of this analysis is that in contrast to a background-conscious approach in monitoring entry to the profession, Germany operates a 'background-blind' system. In other words, the 'Anwaltskammern', bodies that collate information on practising lawyers in each German state, do not collect social background information or university attended and it was not possible to find an individual-level data set to undertake directly comparative analysis.

Third, to complement the literature and the quantitative analysis, one expert interview took place with one of the leaders of a UK-based organization that represents the interests of businesses, including law, who hire university graduates.

\section{Findings}

\section{Comparison of the educational background of leading judges}

Comparing the university backgrounds of leading justices in Britain and Germany results in some striking findings. Of the 12 justices in the UK Supreme Court in 2015, 10 had studied at either Oxford or Cambridge (five at Oxford and five at Cambridge) with the remaining two were graduates from other Russell Group universities (Durham and Belfast). Three of the justices had taken an Oxbridge first degree in a discipline other than law (chemistry, history, unknown). There is one woman and no ethnic minority judges on the Court.

This is very different from the university backgrounds of the 17 judges with chair functions at the Germany Bundesgerichtshof in 2015. First, full educational biographies for the leading German lawyers were more difficult to obtain. Even when other biographical details are provided through publicly available resources, university information was not included half of the time. This finding in itself might already signal the lesser importance the place of university education has for individual's biographical narrative and perhaps in appointment decisions. Of the 9 chairs with valid university data, only one university (Göttingen) is mentioned twice, highlighting a diversity of institutions attended for their studies (Bochum, Frankfurt, Köln, Bonn, Berlin, Bavaria (unspecified) and Erlangen-Nürnberg). A cursory look at the educational biographies of the remaining 111 judges in the supreme court confirms the diversity of educational background with Göttingen remaining one of the few institutions with multiple appearances in the list ahead of Freiburg, an even greater number of undisclosed university attendances, and a growing list of diverse universities such as Kiel, Trier, Frankfurt, Bochum, Marburg, Mainz, Bayreuth and Gießen. Furthermore, some justices attended more than one university for their degree reflecting the custom of students in German higher education - certainly before the Bologna reforms - to split their degree time across two universities. Indeed, future lawyers often undertook further geographic moves for their Referendariat (practical training) or PhD study where this was applicable.

With regards to the Bundesverwaltungsgericht, biographical details were even more elusive for the 54 justices with half (27) not easily available at all, for a further 7, biographical data was available but did not include university studied leaving only 20 entries with university information. Of the 21, six list only their $\mathrm{PhD}$ awarding institution, with the list only containing unique mentions (Bochum, Frankfurt, Freiburg, Mainz, Marburg, Tuebingen), 8 mention their $\mathrm{PhD}$ and law degree award universities with Goettingen being the only institution to appear twice in the diverse list that otherwise includes a range of institutions 
(Passau, Munich, Heidelberg, Hanover, Cologne, Wuerzburg, Berlin - bearing in mind that two list different institutions for their first degree and $\mathrm{PhD}$ ). Those 5 who name only their Staatsexamen awarding university and do not hold $\mathrm{PhDs}$, there is again no double mentioning of institutions (Bonn, Freiburg, Hamburg, Munich, Freiburg). Two justices mention study abroad, one at Galway and one at Grenoble and Cambridge.

Some biographical data was available for all the 16 justices of the Bundesverfassungsgericht. Given that these are leading legal academics, they generally held a first $\mathrm{PhD}$ as well as a Habilitation, a type of second $\mathrm{PhD}$ that used to be compulsory for obtaining academic posts. The universities attended by the 16 justices again include quite a mix of institutions: Muenchen (5x), Kiel (2x), Berlin (2), Mannheim (2x), Gottingen (2x), Muenster, Hamm, Dusseldorf, Bonn, Saarbrucken, Schleswig, Hamburg, Tuebingen, Trier, Mainz, Heidelberg, Speyer, Wiesbaden, Freiburg, Frankfurt, Giessen and Dresden. In terms of overseas experiences, ten of the 16 justices had some overseas experiences either as students or (visiting) law school appointments including these institutions: Michigan Ann Arbor (4), Geneva (2), Pantheon-Sorbonne (2), Harvard (2), University of Miami, Yale, Philadelphia, Aix-en-Provence, Dijon, Grenoble, Pantheon-Assar, Lyon, Budapest, Krakow, Turku, Lissabon, Cagliari. The diversity of overseas institutions and an overall dominance of European and within Europe, French universities, is perhaps another indicator of the range of experiences but also experience of working successfully with European neighbours that are valued for appointments to the highest legal positions in Germany.

Overall, there is no single university that dominates the background of German lawyers. Perhaps worth noting though is the absence of graduates from Eastern German universities which will largely be a time-lag effect since the re-unification of 1990 in light of the age of judges when they reach the highest echelons of their professions.

Finally, considering gender, of the 17 leading judges at the Bundesgerichtshof, 12 are male and 5 are female yielding a 29 per cent female representation. For the

Bundesverwaltungsgericht, there are 40 male judges and 14 female giving a figure of 26 per cent female representation. For the Bundesverfassungsgericht, the female representation is 38 per cent representing the 6 female justices among the 16 justices. These German figures compare with a representation of women of 8 per cent (1 out of 12) for the UK Supreme Court.

The finding that university attended is a key feature of English judges' CVs but not of German judges' CVs is repeated when looking at leading law firms in Germany and England. Again, partners in the most elite 'magic circle' law firms in England are disproportionately recruited from Cambridge and Oxford, while the university attended of German partners either does not feature on their resume or there is no clear dominance of one institution. In contrast to German judges, where international experiences do not feature prominently, some partners in law-firms are international recruits. Where this country has a hierarchical system as in the US, there is a dominance of Ivy League degrees among partners, but where such hierarchy does not exist as clearly - for example, Italy - a greater diversity of institutions is represented among staff in leading law firms. 
The present article builds on the previous work of entry into the legal Bar by undertaking new analysis of the pupillage data set previously described and showing the relationship between the type of university attended and specialism in law.

First, table 1 shows the relationship between the type of university attended and the type of law new barristers are entering. Here, there is a striking over-representation of Oxbridge graduates among those entering the commercial Bar and an under-representation among those doing family and criminal as well as government law. Those from universities outside Oxbridge and the Russell Group are over-represented among those doing family and criminal law.

Table 1: University attended and area of practice among new barristers (figures are in per cent, apart from $n$ which is the number of observations)

\begin{tabular}{|r|c|c|c|c|c|}
\hline University Attended & Oxbridge & Russell Group + & Other & missing & Total \\
\hline Area of Law & & & & & \\
\hline 'commercial' & 51 & 32 & 18 & 31 & 34 \\
\hline 'family and crime' & 11 & 29 & 44 & 27 & 27 \\
\hline government & 3 & 6 & 7 & 7 & 6 \\
\hline Other & 18 & 12 & 7 & 11 & 11 \\
\hline Total & 100 & 14 & 17 & 18 & 17 \\
\hline $\mathrm{N}$ & 256 & 293 & 218 & 188 & 955 \\
\hline
\end{tabular}

\section{Coding note:}

Russell Group + includes institutions that joined the Russell Group after the pupils had graduated, namely, York and Durham. St Andrews and Trinity College Dublin have also been integrated into this group as they are highly ranked and the career prospects of their students closely resembles other Russell Group institutions. Area of practice details: The 'Other' group includes Intellectual Property, environment, general, planning, construction, media, multiple expertise. Government includes administrative law.

A second analysis then illuminates the relationship between the type of university attended and the type of clients the new barristers serve. The striking pattern here is the overrepresentation of those from 'Other' (non Russell Group or Oxbridge) universities who serve individual clients. Oxbridge graduates disproportionately serve 'high-end individual and corporate' and/or 'corporate' clients. 
Table 2: University attended and type of client among new barristers (figures are in per cent, apart from $n$ which is the number of observations)

\begin{tabular}{|l|c|c|c|c|c|}
\hline & Oxbridge & $\begin{array}{l}\text { Russell } \\
\text { Group }\end{array}$ & Other & missing & Total \\
\hline $\begin{array}{l}\text { 'high-end } \\
\text { individual' }\end{array}$ & 1 & 1 & 0 & 1 & 1 \\
\hline $\begin{array}{l}\text { 'individual' } \\
\text { 'high-end } \\
\text { individual' and } \\
\text { corporate' }\end{array}$ & 15 & 7 & 4 & 8 & 9 \\
\hline $\begin{array}{l}\text { 'corporate' } \\
\begin{array}{l}\text { 'other mixture } \\
\text { corporate individual' }\end{array}\end{array}$ & 34 & 17 & 11 & 24 & 21 \\
\hline $\begin{array}{l}\text { 'individual, } \\
\text { corporate and other' }\end{array}$ & 16 & 13 & 15 & 10 & 14 \\
\hline $\begin{array}{l}\text { 'individual and } \\
\text { other' }\end{array}$ & 3 & 6 & 8 & 6 & 14 \\
\hline $\begin{array}{l}\text { 'dissolved' } \\
\text { 'missing' }\end{array}$ & 0 & 1 & 3 & 2 & 2 \\
\hline Total & 261 & 302 & 226 & 195 & 984 \\
\hline N & 100 & 100 & 100 & 100 & 100 \\
\hline
\end{tabular}

A third analysis then considers the impact of having studied law as an undergraduate degree or having come to law through a conversion course, type of law, clients served, and university attended. This is because of the position of non-law graduates being able to enter legal careers after a relatively short one-year conversion course.

Overall, 777 valid observations were available for this analysis, of which 69 per cent or 536 new barristers studied law as their first degree and 241, or 31 per cent, studied a degree other than law as their undergraduate. There is a slightly higher-than-expected representation among the non-law graduates within commercial law where they constitute 35 per cent and an under-representation in family law and crime where the non-law graduates are 23 per cent compared with an expected representation of 31 per cent.

\footnotetext{
2 According to the "2013 World Wealth Report" by Capgemini and RBC Wealth Management, high net worth individuals are those who have US\$1 $\mathrm{m}$ or more of investable assets excluding primary residence, collectibles, consumables and consumer durables $<$ https://www.capgemini.com/resource-fileaccess/resource/pdf/wwr 2013 1.pdf $>$ at p. 4 (last accessed 9 October 2016).
} 
Table 3: Type of first degree and type of university attended (figures are in per cent, apart from $n$ which is the number of observations)

\begin{tabular}{|l|c|c|c|c|c|}
\hline & Oxbridge & $\begin{array}{l}\text { Russell } \\
+\end{array}$ & Other & missing & total \\
\hline Law degree & 54 & 72 & 82 & 90 & 69 \\
\hline Other degree & 46 & 28 & 18 & 10 & 31 \\
\hline Total & 100 & 100 & 100 & 100 & 100 \\
\hline N & 256 & 293 & 218 & 10 & 777 \\
\hline
\end{tabular}

Regarding the link between the degree awarding institution for the new barristers' first degree and their degree type, there are statistically significant associations (tested using crosstabulations and significance based on adjusted residuals and chi-square statistics, with $\mathrm{p}<.001$ used as a cut-off for significance, analysis not shown). Specifically, Oxbridge graduates are most likely to have studied a non-law degree and then to have undertaken a conversion course, almost half ( 46 per cent) have followed this route. This contrasts with fewer than 1 in 5 among the graduates from 'other' universities having taken this route - in other words, the higher the status of the university, the more likely that the law degree is a conversion course.

The final two analyses from the pupillage data set look at the impact of university attended and law degree status on being at the high-end and low-end of earning potential within the Bar. The area of practice with perhaps the most potential for high earnings is commercial law when it serves high-end individual or large corporate clients. In contrast, the area of law with generally lower earnings - and, some would argue, lower prestige - would be family and criminal law serving individual clients. A caveat to this analysis is that the classification of high-end and low-end is rather crude and there will be individual exceptions of people earning a lot of money in family and crime and some not reaching high earnings in the commercial Bar.

With only 47 new barristers classified as being in the high-end group, it makes sense to offer a description of these lawyers as the underlying numbers are too small for a multivariate statistical analysis. With a count of 19 , women are marginally (but not statistically significantly) under-represented among this group. Ethnicity does not impact on the probability of being or not being classified as high-end. There are six new tenants with a BVC grade of outstanding in this group, an over-representation that approaches statistical significance. A strongly significant effect, however, is the over-representation of Oxbridge graduates who make up 22 individuals in this group, there is a converse statistically significant under-representation of graduates from neither Oxbridge nor other Russell Group institutions. Graduates with a First class degree are over-represented among the high-end Bar and those with an Upper Second and degree classes below are under-represented. There is no difference among the law and non-law degree holders in accessing this high-end area of practice.

Looking at the other end of the spectrum, it is possible to single out those who are practising in family and crime and serving only individual (not high-end individual) clients. For solicitors, these would be high-street practices, although the barristers included in this analysis are more specialized. With 137 observations in this group, it is possible to undertake 
a multivariate analysis. A binary logistic regression analysis predicting being in the lowerend Bar was undertaken and is displayed in Table 4.

The results from the analysis show that women are more likely than men to be in this area of the Bar, this is statistically significant. Ethnicity does not have any effect. Having a law degree as compared with having come to law through a conversion course is a significant predictor of practising family or criminal law and serving individual rather than corporate clients. This effect is only to a small extent accounted for by grades and the type of university attended. Those with a First class degree are less likely than lower attaining graduates to be in the family and crime Bar, but there is no further 'net' effect of the grades attained in the then Bar Vocational Course. Finally, Oxbridge graduates are underrepresented among the low-end Bar whereas having graduated from an institution outside Oxbridge and the Russell Group is a significant predictor of being in this area of practice.

Table 4: Predictors of being in family and crime, serving individual (non-high-end) clients. $(\mathrm{B}=$ Beta coefficient, S.E. $=$ standard error $)$

\begin{tabular}{|r|l|l|l|l|l|l|l|l|}
\hline & B & S.E. & B & S.E. & B & S.E. & B & S.E. \\
\hline Predictors & & & & & & & & \\
\hline Female (comparison: male) & $.59 * * *$ & .19 & $.61 * * *$ & .22 & $.57 * *$ & .22 & $.51^{* *}$ & .22 \\
\hline Nonwhite (comparison: white) & -.02 & .24 & -.12 & .26 & -.19 & .27 & -.22 & .27 \\
\hline $\begin{array}{r}\text { Law degree (comparison: Non- } \\
\text { law degree) }\end{array}$ & & & $1.04 * * *$ & .29 & $.99 * * *$ & .29 & $.79^{* * *}$ & .29 \\
\hline $\begin{array}{r}\text { First class degree (comparsion: } \\
\text { Lower attainment) }\end{array}$ & & & & & $-.79 * *$ & .33 & $-.65^{*}$ & .34 \\
\hline $\begin{array}{r}\text { BVC grade outstanding } \\
\text { (comparison: lower attainment) }\end{array}$ & & & & & .38 & .44 & .60 & .46 \\
\hline $\begin{array}{r}\text { University attended } \\
\text { (comparison: Russell Group+) }\end{array}$ & & & & & & & & \\
\hline Oxbridge & & & & & & & $-1.10^{* * *}$ & .34 \\
\hline Other & & & & & & & $.53 * *$ & .23 \\
\hline Missing & & & & & & & $\sim$ & $\sim$ \\
\hline Chi-square & -2.09 & .15 & -2.92 & .28 & -2.73 & .30 & $-2.53 * * *$ & .33 \\
\hline Df & 9.92 & $* *$ & 26.1 & $* * *$ & 32.74 & $* * *$ & 63.44 & $* * *$ \\
\hline $\mathrm{n}$ & 2 & & 3 & & 5 & & 8 & \\
\hline Signtant & 777 & & 777 & & 777 & & 777 & \\
\hline
\end{tabular}

Significance: $* * * \mathrm{p}<.001 ; * * \mathrm{p}<.05 ; * .10$

To recapitulate, while it would have been desirable to undertake a comparative analysis with individual-level German data, this was not possible as such a comparative data set does not exist.

To complement the quantitative analysis, one expert interview was conducted that took place over the telephone in autumn 2015. The motivation here was to gauge whether the findings from the quantitative data analysis enjoy face-validity when triangulated with the experience of a practitioner expert working with law graduates. The respondent represents the interests of UK organisations that recruit university graduates, but the organization had strong European and other international networks and could thus also compare and contrast how hiring of law graduates in England compared internationally. 
The respondent noted that selection in England was usually based on evaluating generic skills and not selection based on the core knowledge acquired through a degree. Even for selecting lawyers one was:

"trying to compare a history graduate with an accountancy and finance candidate - and there is more on the job training in the UK than in, for example, America or Europe where you would have done most professional qualifications at university- in Europe, at least in the graduate recruitment industry... the degree somebody chooses to study has a much... stronger effect on what career they'll go in to."

The respondent elaborated how graduates with a background other than the discipline that was directly relevant to their employment were particularly valued by UK employers:

"often say that they look at their own intake, those who have a non-relevant degree outperform those who have done a degree in this subject ....it's known in the sector... I don't think it's published... But I've known employers who've looked at their own intake with reference to the people they've hired over the last three years, they're trying to understand where the talent is, and it is the non-relevant degrees...there is talent in other fields, it is about thinking ability, attitudes, ability to solve problems as well as the skills the subject bring to the organisation."

He went on to speculate that "If you approach a [legal] training contract from the point of limited knowledge, you have a more open mind, but if you have a relevant-degree, they might think they know it all or find it too easy - there are different dynamics at play."

When asked to comment on the relative importance of having attended a particular university or having studied a particular subject, the verdict was clearly in favour of the high status institution rather than the skills acquired in a degree:

"you're better off going to Oxford and Cambridge and studying history, than going into a lesser known university and studying law."

\section{Discussion}

The present article set out to illuminate the relationship between university attended and first subject studied the legal profession in both Germany and England.

The study reviewed the profile of judges at the highest courts in both countries and the offered a new analysis of the stratification of area of practice and clients served for the English legal Bar and one expert interview with a representative of a graduate recruiter organisation that allowed insights into law graduate hiring in international comparison.

The comparative element of this project has limitations in that not only the two legal systems and their training are very different but also in that Germany generally does not collect basic social background and university information the way England does. Indeed, previous work on German lawyers has been hampered by this very lack of available individual-level information (Hartmann, 2012). However, the new empirical analysis taken together with a 
novel review of both English and German literatures on lawyers still allow for some inferences regarding the role of university attended in the two countries.

There is a long history of work linking shared social and educational backgrounds to elite formation, for example, Mills' work on the US (Mills, 1956) and that social background and educational institutions interact to influence the employment and earning power of graduates (Brennan and Shah, 2002), a finding that is replicated for the new barristers in England. Especially, two key elite universities, Oxford and Cambridge, emerge as educational institutions fulfilling a key gatekeeping function for accessing the most lucrative section of the legal Bar and continue to create new elite groups within the legal Bar (c.f. van Zanten, Ball and Darchy-Koechlin, 2015; Mangset, 2015). This effect cannot be attributed to the uniqueness of the law degree programmes at e.g. Oxbridge, indeed, there is something about the generic Oxbridge experience that allows non-law graduates and law graduates to succeed at the Bar. The fact that non-law graduates benefit greatly from an Oxbridge education indicates the existence of sponsorship by institution type (Turner 1966) but it also shows that general skills, perhaps a 'liberal education', 'culture générale' or soft skills are rewarded in access to elite legal jobs (cf. Oger, 2008; Mangset, 2009; 2015; Brown and Hesketh, 2004). Indeed, research on solicitors has shown that legal knowledge is assumed and firms and chambers thus look for other attributes with Oxbridge degrees used as a proxy for desirable skills (Kumra and Vinnicombe, 2008, Somerlad et al., 2013).

The ability to comprehend that a non-law degree is beneficial for accessing the elite tiers of the legal position is not universally shared and is arguably a mechanism for middle class social closure (cf. Zanten 2009). For example, those seeking to study law to be socially mobile and without the tacit knowledge of how legal hiring work might be tempted to take Alevels in law in secondary school. This can be disadvantageous as some Russell Group universities consider law at A-level an unsuitable or 'non-preferred' preparation for studying law at university (e.g. LSE 2016).

This system of an Oxbridge bonus co-exists alongside a contest system where grades are also important for understanding the stratification of area of practice and clients for early career barristers. However, good grades from a lower ranking university are first of all less common as grades are supposedly standardized across UK institutions. Secondly, high grades do not fully compensate for the lack of an elite education. The finding is supported by the qualitative interview which highlighted the seminal importance of university attended rather than discipline specific technical skills for graduate recruiters.

With the surge and dominance in public discourses of social mobility initiatives in Britain, it is also noteworthy that these appear to reinforce the hierarchical university system rather than providing a perhaps more skills-based alternative model. For example, there are initiatives to open up law notably through the 'Pathways to Law' initiative by the Sutton Trust (since 2006). But with, 11 of the 12 current partner universities on the 'Pathways to Law' programme being Russell Group universities (including Oxford), the Pathway programme might, inter alia, reinforce the salience and dominance of university attended for legal careers. Another example here is the partnership by one of the five magic circle law-firms, Clifford Chance with Oxford University's Moritz-Heyman scholarship scheme for disadvantaged young people. This again demonstrates the ability of law firms to effectively buy into the social mobility agenda and to seek to widen the diversity of background among their graduate intake while still working within the parameters of the hierarchical higher education system that gives a premium to an Oxbridge education. In other words, the gate- 
keeping and access function of elite universities to be more inclusive is key for increasing diversity among graduate entry professions like the Bar later on. It may, of course, be that the Oxbridge education of one-on-one tutorials and argumentation provides not only a signal of socialization but some genuine skills that are useful in the part of the English legal profession historically built around oral arguments.

In contrast, the university attended does not have the same solidarity-forming or signalling function for German lawyers. The analysis showed that entry to the highest judging positions is primarily dependent on attainment at university, thus showcasing an ideal-typical contest system (Turner 1966). The profile of senior judges shows a great diversity of educational backgrounds. Historically, student satisfaction among German law students has been consistently low - regardless of social origin (Bagel, 2007) - thus perhaps highlighting that university is not the key mechanism that provides enjoyable or perhaps even desirable experiences for transition into the most lucrative areas of law.

Indeed, it is only recently that Germany has tried to introduce elite universities into the historically dual higher education system. A relatively recent player is a private law university in Hamburg, and graduates here are anecdotally doing well in the competition for entry to law firms. In this sense, it remains to be seen whether Germany will experience the invention of elite university ethos and whether there might be a narrowing of the university basis of successful lawyers in the future.

However, while lawyers' alma mater may not be decisive in career trajectories, there are some proxy mechanisms at play in Germany which may serve to indirectly aid middle-class reproduction. For example, families need to invest in 'personal capital' like international experiences and fluency in English if they want their children to be rewarded with employment in high-earning multinational companies (Brown, 2013). Moreover, while higher education is generally free, law studies in Germany require revision classes, usually offered by practising lawyers and subject to charges. German universities also have a fraternity system and connections here might matter even if they work in a different way from the Oxbridge connection observed in England and Wales. The analyses in the present article are insufficient to establish key additional factors other than attainment that might differentiate career entry German lawyers. Further mixed methods work could investigate the packaging of law graduates by social background and institution attended in Germany, although the different approach to monitoring and generally to personal data in Germany make it highly unlikely that it would be possible to construct an individual -data set using existing administrative or transactional data akin to the pupillage data set in England.

The type of university attended is key to understanding early career entry among the elite tier of the English legal profession, the English Bar. For Germany, key to success are high grades which are hard to come by and should ideally be complemented with a portfolio of experiences that appear to be more accessible to middle class families. In doing so, the paper has established that the selection modes or folk norms in the two countries are fundamentally different. (Turner 1966). An interesting related question - indeed, some scholars would argue, a more important question - not empirically investigated here - is whether, overall, there is more opportunity for disadvantaged young people hoping to use a law as their engine for social mobility in either country. It is possible that through outreach and increasing opportunities for poorer students to access elite education, the Oxbridge sponsorship can provide a turbo-boost to the future careers of those thus selected to join the future elite by virtue of the university that admitted them. In the absence of direct institutional sponsorship, 
disadvantaged aspiring German lawyers will need to win the competition for the best grades at university, perhaps against the odds of less access to the hidden curriculum of universities and less financial capital to access paid-for revision courses. The default hypothesis would be that, despite the different mechanism of elite reproduction in law, social fluidity in the two countries will be similar, a hypothesis already stated in the 1970s and, while strongly debated and disputed, not conclusively refuted since (Featherman et al., 1975).

To conclude then, the present article showed that type of university, but not type of degree matter greatly for access to the most prestigious and highly paid parts of the legal profession in England with Oxbridge graduates particularly over-represented among the Supreme Court justices and the highest paying tiers of the commercial law Bar. Being male also continues to be associated with holding the most highly paid positions. In contrast, German justices and lawyers in leading law firms show a great heterogeneity of university attended, overseas experiences and among the justices, there is a higher female representation. However, they have uniformly attained the highest grades in their examinations with exam performance being the most important criterion for entering the high-prestige state-employed legal profession. German law firms also value international experiences and additional graduate qualifications for hiring. The role of higher education in transmitting skills versus status and the detailed mechanism for accessing the highest echelons of the ancient legal professions in the two countries is thus very different, although it is unclear whether these differences make law more or less likely to be a route for upward mobility in either country.

Finally, a fruitful avenue for further research could evaluate more closely the link between the different legal systems and legal cultures and the knowledge requirements that arise does a common law system inherently require different professional skills and thus potentially educational experiences from legal systems like the German one which is built on the application of statutory laws? This would shed an interesting light on the relationship between different meta-system structures in counties, in this case, law and education.

\section{Address for correspondence}

Dr Anna Mountford-Zimdars, Senior Lecturer in Higher Education, King's College London

Email: anna.mountford-zimdars@kcl.ac.uk

\section{References}

Bar Council (2014) Representing the Bar Annual Report 2013/14

Bargel, $\mathrm{H}$ and Bargel, T (2010). Ungleichheiten und Benachteiligungen im Hochschulstudium aufgrund der sozialen Herkunft der Studierenden (Inequality and disadvantage in university education by students 'social origin). Hans Boeckler Stiftung.

Bargel, T (ed) (2007) Soziale Ungleichheit im Hochschulwesen: Barrieren für Bildungsaufsteiger (Social Inequlity in higher education: barriers for first in family students). Universität Konstanz, Arbeitsgruppe Hochschulforschung.

Brennan, J and Shash, T (2003) "Access to what? Converting educational opportuity into employment opportunity". Report for HEFCE. Centre for higher education and research information. London: The Open University. 
Brown, P and Hesketh, A. (2004) The mismanagement of talent. Employability and talent in the knowledge economy. Oxford: Oxford University Press.

Brown, P (2013). 'Education, opportunity and the prospects for social mobility", British Journal of Sociology of Education, 34(5-6): 678-700.

Buchhorn, E (2013). Juristen auf Jobsuche: Anwälte als Zeitarbeiter (The job search of law graduates: lawyers as temporary employeers), Spiegel Online, 22.07.2013

Bülow, A (2013) Berufsstart junger Juristen: Prädikat besonders wertvoll (Career entry for young law graduates: outstanding exam results are particularly valuable), KarriereSpiegel, 28.07.2013

Croxford, L., \& Raffe, D. (2014) Social class, ethnicity and access to higher education in the four countries of the UK: 1996-2010. International Journal of Lifelong Education, 33(1), 77-95.

Dahrendorf, R. (1965) Arbeiterkinder an deutschen Universitäten. Mohr Siebeck, Tübingen.

Jerrim, J. (2013) Family background and access to 'high status' universities. London: Sutton Trust.

Featherman, DL, Jones, F.L., Hauser, R.M (1975) Assumptions of Social Mobility Research in the US: The Case of Occupational Status', Social Science Research, 1975

Fielding, H (1996) Bridget Jones Diary. London: Picador.

Gradl, B (2013) Diese Berufsgruppen vertreten das deutsche Volk (An overview of the occupations representing the German people), Die Welt, 06.10.2013

Hartmann, M (2002) Der Mythos von den Leistungseliten: Spitzenkarrieren und soziale Herkunft in Wirtschaft, Politik, Justiz und Wissenschaft (The myth of the meritocracy: top jobs and social origin in the economic, political, legal, and research sectors). Frankfurt, New York: Campus.

Hartmann, M (2012) Sozialer Aufstieg in Deutschland immer schwerer: Vom Tellerwäscher zum Millionär?, (Social mobility in Germany is getting more difficult: From dishwasher to millionaire?) Studies Online, viewed on 31.01.2016, available at: http://www.studis-online.de/HoPo/art-1428-interview-hartmann.php

Hunter, Rosemary (2015) More than Just a Different Face? Judicial Diversity and Decisionmaking, Current Legal Problems, first published online April 27, 2015

Kumra, S and Vinnicombe, S (2008) A Study of the Promotion to Partner Process in a Professional Services Firm: How Women are Disadvantaged, British Journal of Management, 19 (1), pp. 65-74.

Law Society (2015). Trends in the solicitors' profession Annual Statistics Report 2014.

London School of Economics (2016) LSE's entry requirements. Viewed on 31.01.2016, available at:

http://www.lse.ac.uk/study/undergraduate/howToApply/lseEntryRequirements.aspx

Mangset, M. (Forthcoming). "What does it mean to be part of the elite? Comparing Norwegian, French and British top bureaucrats' understandings of the elite concept when applied to themselves." Comparative Sociology.

McGuinness, F (2010). Social background of MPs, House of Commons Library 13.Dec.2010. Mills, Charles Wright (1956) The Power Elite. New York: Oxford University Press.

Mommsen, T, Krueger, P and Watson, A. (1985) The Digest of Justinian. Philadelphia, University of Pennsylvania Press

Schultz, Ulrike and Shaw, G. (2013). Gender and Judging. Oxford: Hart Publishing.

Sommerlad, H; Webley, L.; Duff, L, Muzio, D; Tomlinson, J; Parnham, R. (2013) Diversity in the legal profession in England and Wales: A qualitative study of barriers and individual choices. London: Legal Services Board.

The Sutton Trust (2005) The Educational Backgrounds of the UK's Top Solicitors, Barristers and Judges, London: Sutton Trust. 
Turner, R.H. (1966) Acceptance of Irregular Mobility in Britain and the United States. Sociometry, 29: 334-52.

Van Lijnden, Constantin (2011) Vier gewinnt nicht (Four does not win), Legal Tribune Online 09.06.2011

van Zanten, Agnès, Ball, Stephen J., and Darchy-Koechlin, Brigitte (eds.) (2015) World Yearbook of Education 2015. Elites, Privilege and Excellence. The National and Global Redefinition of Educational Advantage. New York: Routledge.

van Zanten, Agnès (2009). "The sociology of elite education” Pp. 329-339 in International handbook of the sociology of education, edited by Michael Apple, Stephen J. Ball and Luis Armando Gandin. London/New York: Routledge.

Wissenschaftsrat (2012) Prüfungsnoten an Hochschulen im Prüfungsjahr 2010: Arbeitsbericht mit einem Wissenschaftspolitischen Kommentar des Wissenschaftsrates (Examination grades in higher education for the examination year 2010: a report with a scientific commentary by the Science Council).

Zimdars, A. (2010) The Profile of Pupil Barristers at the Bar of England and Wales - 20042008, International Journal of the Legal Profession, 17 (2),pp. 117-134.

Zimdars, A. (2011) The Competition for Pupillages at the Bar of England and Wales (20002004), Journal of Law and Society, 28 (4), pp. 575 - 603.

Zimmermann, Stefanie (2014) JobTrends Deutschland 2014 Jura: Eine Sonderauswertung. (Job trends in Germany 2014: A special analysis concerning law) Staufenbiel Institut. 